University of Nebraska - Lincoln

DigitalCommons@University of Nebraska - Lincoln

Faculty Papers and Publications in Animal

Science

Animal Science Department

January 1981

\title{
MEASURES OF RACETRACK PERFORMANCE WITH REGARD TO BREEDING EVALUATION OF TROTTERS
}

\author{
M. J. Ojala \\ University of Helsinki, 00710 Helsinki 71, Finland \\ L. Dale Van Vleck \\ University of Nebraska-Lincoln, dvan-vleck1@unl.edu
}

Follow this and additional works at: https://digitalcommons.unl.edu/animalscifacpub

Part of the Animal Sciences Commons

Ojala, M. J. and Van Vleck, L. Dale, "MEASURES OF RACETRACK PERFORMANCE WITH REGARD TO BREEDING EVALUATION OF TROTTERS" (1981). Faculty Papers and Publications in Animal Science. 339. https://digitalcommons.unl.edu/animalscifacpub/339

This Article is brought to you for free and open access by the Animal Science Department at DigitalCommons@University of Nebraska - Lincoln. It has been accepted for inclusion in Faculty Papers and Publications in Animal Science by an authorized administrator of DigitalCommons@University of Nebraska - Lincoln. 


\title{
MEASURES OF RACETRACK PERFORMANCE WITH REGARD TO BREEDING EVALUATION OF TROTTERS
}

\author{
M. J. Ojala ${ }^{1}$ and L. D. Van Vleck ${ }^{2,3}$ \\ University of Helsinki, 00710 Helsinki 71, Finland
}

\begin{abstract}
Summary
Trotting records on the Finnish Horse were divided into two subsets: the total data set, with 13,000 race records on 554 horses by 206 sires, and the summary data set, with 1,378 records summarized annually for each horse. The purpose of the study was to determine whether these data could be utilized in a simple, yet useful way for the assessment of breeding value. A total of 24 measures of performance based on time at finish, money won and rank at finish were studied in the summary data set. The total data set included four traits compiled from records made at ages of 3 through 6 years. The proportion of horses that started races and at the end of a race year had records different from those of unraced horses, i.e., different from zero, was 95, 82 and 40 through $77 \%$ for measures of performance based on time, money and rank, respectively. Simple correlations between best and average time for a year were in excess of .90. Repeatabilities for time at finish during a year were about .70. Both estimates imply that time records are relatively consistent over an entire year. Estimates of heritability for best time were about .30 , whereas those for money and rank traits were small or even negative. The results from this study support the concept that best time in a year is the most useful measure for assessing sire breeding values based on progeny records.

(Key Words: Race Track Traits, Repeatability, Heritability, Trotters.)
\end{abstract}

\section{Introduction}

A record system is needed to assess breeding

\footnotetext{
${ }^{1}$ Dept. of Anim. Breed.

${ }^{2}$ Dept. of Anim. Sci., Cornell Univ., Ithaca, NY 14853.

${ }^{3}$ To whom correspondence should be addressed.
}

values for any class of animal. Considerable data are being accumulated by horse racing associations. These records are necessary for supervision of parimutuel races, but also provide a source of information for the selection of breeding stock.

In Finland, the outcome of each harness race is recorded for each horse in three forms-time at finish, money won and rank at finish-each of which can be considered as an indicator of performance. Instead of using individual records for a horse (the total data set, TDS), the information is summarized annually for each horse (the summary data set, SDS). Various measures of performance (traits) can be derived from each of the three basic sources of information.

In both harness and flat racing, numerous traits derived from the same basic source of information are simultaneously reported to describe track performance. Thus, for selection purposes, estimates of genetic properties of the different traits should be known. A related question is whether best time in a year is representative of time records made by a horse in all starts during a year.

Horses that never enter a race create a problem when sire evaluation is based on progeny records. But many horses that have raced also may have records of zero, the same as for unraced horses, since they may not finish the race, win any money or have a rank recorded. The proportion of such horses depends on the measure of performance. For sire evaluation, the most useful trait will allow the greatest number of progeny to have a record different from zero or some other constant.

The purpose of this study was to examine some properties of different measures of track performance to determine whether data accumulated from harness races could be utilized in a simple, yet useful way for genetic evaluation. 


\section{Materials and Methods}

Data were collected from the files of Suomen Hippos, the Finnish Trotting and Horse Breeding Association. Records were made by Finnish Horses born in 1967 or 1968 that took part in trotting races at ages of 3 through 6 years. The Finnish horse is a general purpose breed such as the D $\phi$ le in Norway, the North-Swedish Horse, the Breton in France and the Morgan in North America. At present, the Finnish Horse is used mainly for trotting sport, but is also a work and riding horse, whereas draft was the major usage in the past.

The original and complete set of data included 15,207 records. A record included race performance in three forms: time at finish expressed per unit of distance, prize money won and rank at finish. A record was accepted for analysis only if time and rank at finish were recorded. The absence of an entry for time at finish may, rarely, mean a failure in recording, but more commonly indicates, as was assumed in this work, that a horse was disqualified because it broke stride or because a driver interrupted the race. After editing, there were 13,000 records for 554 horses by 206 sires in the TDS, distributed by age as in table 1.

The records in the original data set also were summarized annually for each horse. The number of records in the SDS was 1,378 , distributed by age as shown in table 1. The measures of performance are given in table 2 .

Age is known to have a major effect on performance. To adjust for age effects, calculations were done separately, where applicable, for each age group. The simplest statistical models were assumed because they are the models assumed in sire evaluation in Finland at present.

Transformation of Variables. A measure of performance whose frequency distribution is

TABLE 1. NUMBER OF RECORDS, HORSES AND SIRES FOR EACH AGE GROUP

\begin{tabular}{lrrrr}
\hline & \multicolumn{4}{c}{ Age of horse } \\
\cline { 2 - 5 } Item & 3 years & 4 years & 5 years & 6 years \\
\hline No. of records & 732 & 2,424 & 4,193 & 5,651 \\
No. of horses & 216 & 362 & 373 & 427 \\
No. of sires & 95 & 147 & 150 & 170 \\
\hline
\end{tabular}

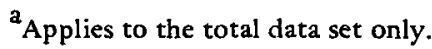

not normal may follow an approximately normal distribution after transformation. Two transformations were applied to money traits: logarithmic, $Y=\ln (X+1)$, and square root, $Y$ $=(X)^{1 / 2}$, where $X$ is the amount of money and ln is the natural logarithm (Snedecor and Cochran, 1967). A square root transformation of rank traits in the SDS was made as $Y=(X+$ $1)^{1 / 2}$, where $X$ is the variable involving counts. Two other transformations were also applied to rank traits: the inverse of the sine (arcsin), $Y=$ $\arcsin (X)^{1 / 2}$, where $X$ is a proportion (Sokal and Rohlf, 1969), and the logit transformation as

\section{TABLE 2. MEASURES OF TROTTING PERFORMANCE IN TWO TYPES OF DATA SETS}

\section{Summary data set}

(A) Measures based on time:

(1) Best time per kilometer out of all starts in a year, abbreviated as best time

(2) Average time

(3) Poorest time

(B) Measures based on money:

(4) Total money won in a year, total money (TM)

(5) Log of TM

(6) Square root of $\mathrm{TM}$

(7) Money won per start in a year, average money (AM)

(8) Log of AM

(9) Square root of $A M$

(C) Measures based on rank:

(10) Number of times a horse finished first in a year, first rank (FR)

(11) Number of times a horse finished first through fourth (FFR)

(12) Number of times time at finish was not recorded, disqualified races (DR)

(13) Percentage of FR races out of all starts in a year, FR-\%

(14) FFR-\%

(15) DR-\%

(16) Square root of $F R$

(17) Square root of FFR

(18) Square root of DR

(19) Arcsin of FR

(20) Arcsin of FFR

(21) Arcsin of DR

(22) Logit of FR

(23) Logit of FFR

(24) Logit of DR

\section{Total data set}

(25) Time at finish per kilometer in a single race

(26) Money won in a race, money

(27) Log of money

(28) Rank at finish in a race 
used by Minkema (1975), $Y=\ln [(X+.5))$ $(100.5-X)]$, where $X$ is the variable consisting of proportions expressed as percentages.

Frequency distributions for all time traits were approximately normal. Among the other measures, distributions for logarithm and square root of average money (AM) and arcsin of number of times ranked first through fourth (FFR) were closest to normality. Frequency distributions for money and rank traits were approximately normal, at best, only if the fraction of horses (or records) with zero performance was deleted. Histograms for each measure were presented by Ojala (1979) for 5-year-old horses.

Estimation of Repeatabilities. Repeatability in the SDS is an estimate for annually summarized records. Each horse was required to have a time record in each of three age groups (4-, 5- and 6-year-olds). Thus, a mixed model analysis of variance for balanced data could be used to estimate the components of variance for the random effects (Sokal and Rohlf, 1969; Searle, 1971). The estimate of repeatability was the estimated intraclass correlation. The method of Swiger et al. (1964) was used to approximate the standard errors of the estimates. The linear model assumed in the SDS was:

$$
y_{i j}=\mu+a_{i}+h_{j}+e_{i j}
$$

where

$y_{i j}$ is the annually summarized record of the $\mathrm{j}^{\text {th }}$ horse at the $\mathrm{i}^{\text {th }}$ age;

$\mu$ is a general mean;

$a_{i}$ is a fixed effect due to the $i^{\text {th }}$ age group;

$h_{j}$ is a random effect due to the $j^{\text {th }}$ horse, IID $\left(0, \sigma_{h}^{2}\right)$, and

$e_{i j}$ is a random error effect, $\operatorname{IID}\left(0, \sigma_{\mathrm{e}}^{2}\right)$, unique to the record of the $j^{\text {th }}$ horse at the $\mathrm{i}^{\text {th }}$ age.

Horse and error effects were assumed to be uncorrelated.

Repeatability calculated from the TDS represents an estimate for single records of a horse at a specific age. Each horse was required to have at least two starts in an age group. The linear model assumed in the TDS for each of the age groups was:

$$
y_{i j}=\mu+h_{i}+e_{i j},
$$

where

$y_{i j}$ is the $j^{\text {th }}$ race record of the $i^{\text {th }}$ horse; $\mu$ is a general mean;

$h_{i}$ is a random effect, IID $\left(0, \sigma_{h}^{2}\right)$, due to the $\mathrm{i}^{\text {th }}$ horse, and

$e_{i j}$ is a random error effect, $\operatorname{IID}\left(0, \sigma_{e}^{2}\right)$, unique to the $\mathrm{j}^{\text {th }}$ record of the $\mathrm{i}^{\text {th }}$ horse.

Horse and error effects were assumed uncorrelated.

Estimation of Heritabilities. Since about twothirds of the sires had only one progeny in each age group, records on offspring of those sires were deleted for heritability calculations. After the variance components were estimated, estimates of heritability were calculated by the intraclass correlation of paternal half sibs (e.g., Van Vleck, 1973). Approximate standard deviations for heritabilities were approximated by the method given by Swiger et al. (1964). The linear model assumed in the SDS for each age was:

$$
y_{i j}=\mu+s_{i}+e_{i j} \text {, }
$$

where

$y_{i j}$ is the annually summarized record made by the $j^{\text {th }}$ offspring of the $i^{\text {th }}$ sire;

$\mu$ is a general mean;

$s_{i}$ is a random effect, IID $\left(0, \sigma_{s}^{2}\right)$, due to the $\mathrm{i}^{\text {th }}$ sire, and

$e_{i j}$ is a random error effect, $\operatorname{IID}\left(0, \sigma_{e}^{2}\right)$, unique to the record made by the $\mathrm{j}^{\text {th }}$ offspring of the $\mathrm{i}^{\text {th }}$ sire.

Sire and error effects were assumed to be uncorrelated.

For the estimation of heritabilities from the TDS, the same restriction was used in editing the data as for the SDS. Thus, the two edited data sets were identical in terms of horses and sires, but in the TDS an offspring of a sire might have had one or more records within an age group. The linear model assumed in the total data set for each of the age groups was:

$$
y_{i j k}=\mu+s_{i}+h_{i j}+e_{i j k} \text {, }
$$

where

$y_{i j k}$ is the $k^{\text {th }}$ race record made by the $\mathrm{j}^{\text {th }}$ offspring of the $\mathrm{i}^{\text {th }}$ sire; 
$\mu$ is a general mean;

$s_{i}$ is a random effect, IID $\left(0, \sigma_{s}^{2}\right)$, due to the $i^{\text {th }}$ sire;

$h_{i j}$ is a random effect, IID $\left(0, \sigma_{h}^{2}\right)$, due to the $j^{\text {th }}$ offspring of the $i^{\text {th }}$ sire, and

$\mathrm{e}_{\mathrm{ijk}}$ is a random error effect, IID $\left(0, \sigma_{\mathrm{e}}^{2}\right)$, unique to the $k^{\text {th }}$ record made by the $\mathrm{j}^{\text {th }}$ offspring of the $\mathrm{i}^{\text {th }}$ sire.

Sire, horse, and error effects were assumed uncorrelated.

\section{Results and Discussion}

A Basic Property of the Measures of Performance. The proportion of horses that had raced and also had a record different from zero varied greatly depending on the measure of performance. The proportion of horses with racing records different from those of unraced horses averaged about 95,82 and 40 through $77 \%$ for traits based on time, money and rank, respectively (table 3 ). Thus, measures of progeny performance based on time seem to be most useful for breeding evaluation of sires. The slight differences in percentages among age groups may be explained partly by differences in average number of starts per horse $(3.5,7.5$, 12.5 and 14.5 for horses aged 3 through 6 ). The percentage of horses that earned some money agrees well with the $85 \%$ calculated from a large set of data on Thoroughbreds (Bloodstock Research and Statistical Bureau, 1979).

Relationships among Measures of Perform. ance. Only simple correlations were calculated. The correlations in the SDS among time traits were large and similar for all age groups. Average correlations for best with average and poorest times were .96 and .76 , respectively, and the correlation for average with poorest time was .88. It should be noted that the highest correlation was that between best and average time. Average correlations across the four age groups for best time with $\log$ of AM and arcsin of FFR were -.66 and -.35 , respectively, and that for $\log$ of AM with arcsin of FFR was .76. Thus, favorable correlations existed among the traits in the three basic trait groups of time, money and rank. Complete tables of correlations among all traits were presented by Ojala (1979).

It was suspected that simple correlations among measures of performance in the SDS might not be the same if records on horses with only a single or a small number of starts in a year were deleted. Number of races in a year, however, seemed to have little or no effect on correlations between best and average time (table 4). The same pattern was observed for correlations among the other traits.

The results listed in table 4 indicate that time records in single races in a year are relatively repeatable. This result is supported by correlations of $.83, .85$ and .72 between best and average time in a year reported by Linner (1975, as cited by Minkema, 1978), Katona (1979) and Neisser (1976). The consistency of time records for individual races is further supported by results reported by Minkema (1975) and Katona (1979). Katona (1979) reported a correlation of .78 for time at finish in first race with average time for that year and of .93 for average time of first four races with average time of all races in a year. Minkema (1975) reported a correlation of .98 for best time in lifetime with average of five best times in lifetime. The absolute magnitudes of correlations among best time, log of AM and arcsin of FFR are slightly smaller than reported by Minkema (1975), but larger than the correla-

TABLE 3. THE FRACTION OF HORSES HAVING RECORDS DIFFERENT FROM THOSE OF UNRACED HORSES FOR SOME BASIC MEASURES OF PERFORMANCE

\begin{tabular}{llccc}
\hline & & \% of horses by age group \\
\cline { 2 - 4 } Measure of performance & 3 years & 4 years & 5 years & 6 years \\
\hline Measures based on time & 95.2 & 93.5 & 93.5 & 96.2 \\
Measures based on money & 78.4 & 78.3 & 82.7 & 86.7 \\
Measures based on first finishes & 26.9 & 34.4 & 47.1 & 52.7 \\
Measures based on first through fourth finishes & 72.7 & 73.1 & 78.2 & 84.9 \\
Measures based on disqualified races & 18.1 & 51.7 & 63.7 & 60.6 \\
\hline
\end{tabular}

${ }^{2}$ Number of horses in age groups 3 through 6 years was 227, 387, 399 and 444, respectively. 
TABLE 4. SIMPLE CORRELATIONS BETWEEN BEST AND AVERAGE TIME IN A YEAR IN RESTRICTED SET OF DATA

\begin{tabular}{|c|c|c|c|c|c|c|c|c|}
\hline \multirow{3}{*}{$\begin{array}{l}\text { Minimum no. of } \\
\text { starts per horse } \\
\text { in a year }\end{array}$} & \multicolumn{8}{|c|}{ Correlations (r) and number of horses $(n)$ at different ages } \\
\hline & \multicolumn{2}{|c|}{3 years } & \multicolumn{2}{|c|}{4 years } & \multicolumn{2}{|c|}{5 years } & \multicolumn{2}{|c|}{6 years } \\
\hline & r & $\mathbf{n}$ & $\mathbf{r}$ & $\mathbf{n}$ & $\mathbf{r}$ & $\mathrm{n}$ & $\mathrm{r}$ & $\mathrm{n}$ \\
\hline 1 & .96 & 216 & .97 & 362 & .95 & 373 & .97 & 427 \\
\hline 2 & .95 & 173 & .97 & 331 & .95 & 356 & .97 & 407 \\
\hline 3 & .94 & 132 & .94 & 281 & .94 & 339 & .97 & 389 \\
\hline 4 & .92 & 92 & .94 & 252 & .94 & 314 & .97 & 371 \\
\hline 5 & .92 & 60 & .93 & 225 & .94 & 295 & .96 & 358 \\
\hline 8 & .95 & 19 & .91 & 153 & .94 & 250 & .96 & 305 \\
\hline 10 & .94 & 6 & .91 & 119 & .93 & 216 & .96 & 275 \\
\hline 15 & $\ldots$ & $\ldots$ & .86 & 55 & .91 & 147 & .96 & 196 \\
\hline 20 & $\ldots$ & $\ldots$ & .91 & 24 & .91 & 85 & .95 & 127 \\
\hline 25 & $\ldots$ & $\ldots$ & .91 & 5 & .91 & 42 & .93 & 81 \\
\hline 30 & $\ldots$ & $\ldots$ & $\ldots$ & 2 & .97 & 25 & .94 & 55 \\
\hline
\end{tabular}

tions from studies by R $\phi$ nningen (1975) and Hellman (1978). A positive correlation between performance rate, which is an annual average of a horse's speed measured in horse lengths relative to the winner, and earnings per start was suggested in Thoroughbreds by the results of Gillespie (1971).

Large correlations for best time with average time in a year imply that best time is a satisfactory measure of average speed in a year. Correlations among annually summarized measures of performance based on time, money and rank were relatively large, supporting the obvious expectation that horses with superior best times tend to rank among the first four in a race and consequently tend to have larger average earnings per start.

Estimates of Repeatability. When the SDS is used, estimates of repeatability are for annually summarized records made at different ages. Repeatabilities for best time, log of AM and arcsin of FFR were about .70, .40 and .30 (table 5). The estimate of repeatability for best time was almost twice that reported by $\mathrm{R} \phi$ nningen (1975). Repeatabilities for best time and average time agree with those of .61 and $.75 \mathrm{re}$ ported by Katona (1979). Repeatabilities for other traits were of about the same magnitude as corresponding estimates for trotters (R $\phi$ nningen, 1975; Katona, 1979) and Thoroughbreds (Foye et al., 1972).

Correlations between two measurements of the same trait at different ages can be interpreted as repeatability of the trait. The simple correlations were relatively consistent over an age range of 4 through 6 years, and their average approximated the estimate of repeatability. Correlations between best times at different ages were slightly larger than those reported for the Finnish Horse by Ojala (1972), but were of about the same magnitude as those reported by Minkema (1975). Correlations between average time in adjacent years agreed with those of Katona and Osterkorn (1977) but were slightly larger than those of Katona (1979).

Estimates of repeatability calculated from the TDS are for records of races in a year. Repeatabilities for time at finish were similar across age groups, varying from .60 to .70 (table 6). Repeatabilities for money and rank traits were smaller, about .15 through .25. Estimates of repeatability for time at finish were almost twice as large as estimates for Standardbred pacers (Solá, 1969; Hintz and Van Vleck, 1978) and Thoroughbreds (Bormann, 1962, 1966). Repeatabilities for other traits were slightly smaller than those reported by Solá (1969) and Hintz (1977).

The simple correlations and estimates of repeatability in the SDS suggest that performance measured by best or average time for a year is quite repeatable in successive years. The large estimates of repeatability in the TDS and the correlations between best and average times imply that performance measured by time at finish is relatively consistent during an entire year.

Estimates of Heritability. Heritability estimates from the SDS for best time in a year averaged about .30 (table 7 ). The heritability 
TABLE 5. ESTIMATES OF REPEATABILITY (r) AND APPROXIMATE STANDARD ERRORS (SE) FOR ANNUALLY SUMMARIZED TROTTING TRAITS AND SIMPLE CORRELATIONS BETWEEN MEASUREMENTS OF THE SAME TRAIT AT 4, 5 AND 6 YEARS OF AGE

\begin{tabular}{llllll}
\hline & & & \multicolumn{3}{c}{ Correlations between age groups } \\
\cline { 5 - 6 } Trait & $\mathrm{r}$ & SE & 4vs 5 years & 4 vs 6 years & 5 vs 6 years \\
\hline Best time & .69 & .03 & .73 & .67 & .79 \\
Avg time & .76 & .02 & .80 & .70 & .86 \\
Poorest time & .53 & .04 & .53 & .48 & .61 \\
Total money (TM) & .28 & .04 & .56 & .57 & .49 \\
Log of TM & .39 & .04 & .39 & .45 & .34 \\
Square root of TM & .50 & .04 & .55 & .58 & .55 \\
Avg money (AM) & .42 & .04 & .58 & .60 & .58 \\
Log of AM & .38 & .04 & .37 & .40 & .37 \\
Square root of AM & .49 & .04 & .49 & .50 & .53 \\
No. of first place finishes (FR) & .40 & .04 & .45 & .41 & .39 \\
No. of first through fourth place finishes (FFR) & .40 & .04 & .42 & .41 & .43 \\
No. of disqualif. races (DR) & .24 & .04 & .36 & .12 & .25 \\
FR-\% & .34 & .04 & .39 & .34 & .32 \\
FFR-\% & .33 & .04 & .29 & .35 & .37 \\
DR-\% & .24 & .04 & .29 & .17 & .26 \\
Square root of FR & .40 & .04 & .44 & .40 & .37 \\
Square root of FFR & .41 & .04 & .40 & .43 & .42 \\
Square root of DR & .26 & .04 & .36 & .14 & .28 \\
Arcsin of FR & .30 & .04 & .34 & .31 & .27 \\
Arcsin of FFR & .29 & .04 & .23 & .33 & .34 \\
Arcsin of DR & .25 & .04 & .30 & .17 & .28 \\
Logit of FR & .27 & .04 & .30 & .29 & .24 \\
Logit of FFR & .23 & .04 & .17 & .29 & .28 \\
Logit of DR & .24 & .04 & .30 & .16 & .26 \\
\hline
\end{tabular}

${ }^{2}$ Data included on 226 horses that had a time record at 4,5 and 6 years of age.

${ }^{b}$ Critical values of $r$ at the 5 and $1 \%$ levels of significance are approximately $r=.13$ and $r=.18$ (Snedecor and Cochran, 1967).

for the 6-year-old group did not agree with estimates for the other age groups. Estimates of heritability for $\log$ of AM and arcsin of FFR were mostly small and varied markedly among the different age groups.

Heritabilities for time at finish estimated from the TDS averaged slightly over 30 for the four age groups (table 8). Estimates of heritability for other traits were mostly small and variable. Heritabilities for time at finish were of about the same magnitude as those for best and average times during a year.

TABLE 6. ESTIMATES OF REPEATABILITY (r) AND APPROXIMATE STANDARD ERRORS (SE) FOR MEASURES OF TROTTING PERFORMANCE FROM SINGLE RACES

\begin{tabular}{|c|c|c|c|c|c|c|c|c|}
\hline \multirow[b]{3}{*}{ Measure of performance } & \multicolumn{8}{|c|}{ Age of horse ${ }^{a}$} \\
\hline & \multicolumn{2}{|c|}{3 years } & \multicolumn{2}{|c|}{4 years } & \multicolumn{2}{|c|}{5 years } & \multicolumn{2}{|c|}{6 years } \\
\hline & $\mathrm{r}$ & SE & $\mathbf{r}$ & SE & $\mathbf{r}$ & SE & $\mathbf{r}$ & SE \\
\hline Time at finish & .74 & .03 & .61 & .02 & .65 & .02 & .74 & .01 \\
\hline Money won & .28 & .04 & .19 & .02 & .18 & .02 & .24 & .02 \\
\hline Log of money & .38 & .04 & .22 & .02 & .14 & .01 & .13 & .01 \\
\hline Rank at finish & .42 & .04 & .24 & .02 & .14 & .01 & .15 & .01 \\
\hline
\end{tabular}

\footnotetext{
${ }^{a}$ Numbers of records and horses in the four age groups were, respectively: 682 and $166 ; 2,372$ and 311 ; 4,161 and 341 , and 5,616 and 392 .
} 
TABLE 7. ESTIMATES OF HERITABILITY $\left(h^{2}\right)$ AND APPROXIMATE STANDARD ERRORS (SE) FOR ANNUALLY SUMMARIZED TROTTING TRAITS

\begin{tabular}{|c|c|c|c|c|c|c|c|c|}
\hline \multirow[b]{3}{*}{ Trait } & \multicolumn{8}{|c|}{ Age of horse ${ }^{a}$} \\
\hline & \multicolumn{2}{|c|}{3 years } & \multicolumn{2}{|c|}{4 years } & \multicolumn{2}{|c|}{5 years } & \multicolumn{2}{|c|}{6 years } \\
\hline & $h^{2}$ & SE & $h^{2}$ & $\mathbf{S E}$ & $\mathrm{h}^{2}$ & $\mathrm{SE}$ & $h^{2}$ & SE \\
\hline Best time & .31 & .29 & .28 & .21 & .33 & .21 & .70 & .23 \\
\hline Avg time & .27 & .29 & .30 & .21 & .45 & .22 & .74 & .23 \\
\hline Poorest time & .08 & .26 & .19 & .19 & .21 & .20 & .67 & .22 \\
\hline Total money (TM) & .75 & .34 & .29 & .21 & -.10 & .16 & -.22 & .13 \\
\hline Log of TM & .04 & .25 & .22 & .20 & -.04 & .17 & .44 & .21 \\
\hline Square root of $\mathrm{TM}$ & .34 & .29 & .41 & .22 & -.01 & .17 & .12 & .18 \\
\hline Avg money (AM) & .20 & .28 & -.01 & .17 & -.05 & .17 & -.24 & .13 \\
\hline $\log$ af $A M$ & -.04 & .24 & .12 & .18 & .03 & .18 & .45 & .21 \\
\hline Square root of $\mathrm{AM}$ & .05 & .25 & .13 & .19 & .03 & .18 & .21 & .18 \\
\hline No. of first place finishes (FR) & .63 & .33 & .38 & .22 & -.16 & .15 & .15 & .18 \\
\hline No. of first through fourth place finishes (FFR) & .30 & .29 & .46 & .23 & -.20 & .15 & .23 & .19 \\
\hline No. of disqual. races (DR) & -.32 & .18 & .02 & .17 & .22 & .20 & .10 & .17 \\
\hline FR-\% & .23 & .28 & .26 & .20 & -.20 & .15 & -.15 & .14 \\
\hline FFR-\% & .10 & .26 & .20 & .20 & .01 & .18 & .28 & .19 \\
\hline DR-\% & -.09 & .23 & .19 & .19 & .21 & .20 & -.04 & .16 \\
\hline Square root of FR & .48 & .31 & .37 & .22 & -.05 & .17 & .23 & .19 \\
\hline Square root of FFR & .21 & .28 & .49 & .23 & -.19 & .15 & .21 & .19 \\
\hline Square root of DR & -.30 & .19 & .03 & .17 & .23 & .20 & .10 & .17 \\
\hline Arcsin of FR & .16 & .27 & .25 & .20 & -.15 & .16 & .01 & .16 \\
\hline Arcsin of FFR & .10 & .26 & .16 & .19 & -.03 & .17 & .34 & .20 \\
\hline Arcsin of DR & -.16 & .21 & .15 & .19 & .24 & .20 & .08 & .17 \\
\hline Logit of FR & .10 & .26 & .22 & .20 & -.13 & .16 & .14 & .18 \\
\hline Logit of FFR & .10 & .26 & .13 & .19 & -.05 & .17 & .38 & .20 \\
\hline Logit of DR & -.19 & .21 & .13 & .19 & .25 & .20 & .14 & .18 \\
\hline
\end{tabular}

${ }^{a}$ Number of horses and sires in the four age groups were, respectively: 151 and $30 ; 259$ and $44 ; 278$ and 55 , and 321 and 63.

Studies based on the Studbook records of the Finnish Horse suggest a high level of heritability, about .40 through .50 , for time in trotting tests (Vainikainen, 1946; Varo, 1965). Estimates for time traits based on trotting races range from .20 to .30 (Gopka, 1971; Ojala,
1972; Kalmykov, 1973; Linner and Osterkorn, 1974; Minkema, 1975; R $\phi$ nningen, 1975; Schwark and Freund, 1976; Dusek, 1979; Katona, 1979). Thus, estimates of heritability for time traits in this study fall near the upper border of previous estimates. The range for

TABLE 8. ESTIMATES OF HERITABILITY $\left(h^{2}\right)$ FOR MEASURES OF TROTTING PERFORMANCE FROM SINGLE RACES

\begin{tabular}{|c|c|c|c|c|}
\hline \multirow[b]{3}{*}{ Measure of performance } & \multicolumn{4}{|c|}{ Age of horse ${ }^{a}$} \\
\hline & 3 years & 4 years & 5 years & 6 years \\
\hline & $h^{2}$ & $\mathrm{~h}^{2}$ & $\mathrm{~h}^{2}$ & $h^{2}$ \\
\hline Time at finish & .41 & .15 & .39 & .32 \\
\hline Money won & .26 & .06 & -.01 & -.11 \\
\hline Log of money & .14 & -.00 & .02 & .01 \\
\hline Rank at finish & .15 & .01 & .00 & .01 \\
\hline
\end{tabular}

${ }^{a}$ Numbers of records, horses and sires in the four age groups were, respectively: 499,151 and $30 ; 1,853,259$ and $44 ; 3,240,278$ and 55 , and $4,387,321$ and 63 . 
time traits based on flat races is about .10 through .30 (Artz, 1961; Bormann, 1962, 1966; Watanabe et al., 1965; Watanabe, 1969, 1970; Kieffer, 1973 ; Neisser, 1976).

Estimates of heritability for untransformed money traits generally range from .20 to .30 (Pirri and Steele, 1951, 1952; Langlois, 1975; Minkema, 1975), whereas the corresponding range for transformed money traits is .30 to .40. Excluding 3-year-olds, heritabilities for money traits were lower in this study than those in the literature. No distinct effect of transformation on the magnitude of heritabilities for money traits was observed in this study.

Estimates of heritability reported in the literature are difficult to summarize because of the great variability in magnitude. In addition, descriptions of size and structure of data sets and even definitions of measures of performance are often insufficient for summarization. In general, estimates of heritability for time traits seem to be similar for both trotters and Thoroughbreds, perhaps slightly smaller for Thoroughbreds. No definite conclusion can be made about the relative sizes of heritabilities for traits based on time, money and rank, because only a few studies included all three or even two of these traits.

\section{General Discussion}

Most horses that have raced have a time record, but not necessarily a money won or rank at finish record, different from that of unraced horses. Thus, for purposes of sire evaluation, a measure of performance based on time at finish is more useful than a measure based on money won or rank at finish. This conclusion contradicts that of Minkema (1975).

Time at finish in single races was relatively consistent for a horse during a year. Thus, best time during a year may be the most useful measure of track performance. In addition, estimates of repeatability and heritability were consistently larger for time traits than for traits based on money and rank. Money and rank traits may have been affected more than time traits by not being adjusted for fixed factors other than age.

By this reasoning, it follows directly that if best time is used for genetic evaluation, single race records are not needed since the summary data are sufficient. On the other hand, if average time or a money trait is used, the total data set should be utilized because the single records should be adjusted for some of the fixed factors. Some of the adjustments required e.g., year (inflation) and racetrack (amount of purse), may be large in the case of money traits. The number of adjustment factors also may be numerous for time at finish. In contrast, best time in a year has some useful properties since the importance of environmental factors such as weather, track and other conditions influencing best time may be minimized if a horse had a chance to start a sufficient number of times. Future research will focus on a horse's best time.

\section{Literature Cited}

Artz, W. 1961. Ein Beitrag zur Auswertung der Leistungsprufungen in der Vollblutzucht unter besonderer Berücksichtigung der Rennleistung einzelner Hengstnachkommenschaften. Giessener Schriftenr. Tierz, Haustiergen No. 2.

Bloodstock Research and Statistical Bureau. 1979. American Produce Records 1930-1978. Bloodstock Research and Statistical Bureau, Lexington, KY, p. 5.

Bormann, P. 1962. Die Anwendung biomathematischer Methoden bei der Auswertung der Rennleistung von Vollblutpferden. Giessener Schriftenr. Tierz. Haustiergen. No, 7 .

Bormann, P. 1966. Ein Vergleich zwishchen Generalausgleichsgewicht und Zeitmessung als Selektionsmasstab in der Vollblutzucht. Züchtungskunde 38:301.

Dusek, J. 1979. Abschätzung der Heritabilitätskoeffizienten der Geschwindigkeit von Trabern der ungarischen und italienischen Zucht. Bodenkultur 30:79.

Foye, D. B., H. C. Dickey and C. J. Sniffen. 1972. Heritability of racing performance and a selection index for breeding potential in the Thoroughbred horse. J. Anim. Sci. 35:1141.

Gillespie, R. H. 1971. Performance rates. Thoroughbred Rec. 193:961.

Gopka, B. M. 1971. Heritability of speed in Orlov trotters. (In Russian.) Genetika i Selektsiya na Ukraine, Keiv Nauk, Dumka, p. 8. (Anim. Breed. Abstr. 40:1334.)

Hellman, T. 1978. Heredity of performance traits in the Standardbred trotter in Finland. (In Finnish.) Hevosurheilu. Jalostuskuvasto $1: 106$.

Hintz, R. L. 1977. Factors influencing racing performance of the Standardbred pacer. Ph.D. Thesis. Cornell Univ., Ithaca, NY.

Hintz, R. L. and L. D. Van Vleck. 1978. Factors influencing racing performance of the Standardbred pacer. J. Anim. Sci. 46:60.

Kalmykov, A. N. 1973. Heritability of economically important traits in the Orlov trotter. (In Russian.) Genetica 9:50 (Soviet Genetics 9:978, an English translation).

Katona, Ö. 1979. Genetical-statistical analysis of traits in the German Trotter. Livestock Prod. Sci. $6: 407$.

Katona, Ö. and K. Osterkorn. 1977. Genetisch-statis- 
tische Auswertung des Leistungsmerkmals Rennzeit in der deutschen Traberpopulation. Zuichtungskunde 49:185.

Kieffer, N. M. 1973. Inheritance of racing ability in the Thoroughbred. Thoroughbred Rec, 198:50.

Langlois, B. 1975. Statistical and genetical analysis of earnings of three-year-old Thoroughbreds in French flat races from 1971 to 1973. (In French with English summary.) Ann. Génét. Sél. Anim. $7: 387$.

Linner, M. Th. and K. Osterkorn. 1974. Ziichterische Auswertung der Rennleistung von Traberpferden der Jahrgainge 1963 and 1964 in der BRD. Zuchtungskuinde 46:168.

Minkema, D. 1975. Studies on the genetics of trotting performance in Dutch trotters. I. The heritability of trotting performance. Ann. Génét. Sél. Anim. 7:99.

Minkema, D. 1978. Leistungsprufung und Zuchtplanung in der Traberzucht. Paper presented at the Annu. Meet. of the European Assoc. Anim. Prod., Stockholm.

Neisser, E. 1976. Evaluation of several criteria to measure performance potential in the Thoroughbred. (In German.) II. Internat'l Wissenschaftliches Symp., Leipzig. (Anim. Breed. Abstr. 47:5291.)

Ojala, M. 1972. Factors influencing the speed of a trotter and the possibilities of improving a trotter's racing ability through selection. (In Finnish.) M.S. Thesis. Helsinki Univ., Finland.

Ojala, M. J. 1979. Considerations in utilizing race track records in breeding trotting horses. M.S. Thesis. Cornell Univ., Ithaca, NY.

Pirri, J., Jr. and D. G. Steele. 1951. Heritability of racing capacity in Thoroughbreds. J. Anim. Sci. 10: 1029 (Abstr.).

Pirri, J., Jr. and D. G. Steele. 1952. The heritability of racing capacity. The Blood-Horse 63:976.

Rønningen, K. 1975. Genetic and environmental factors for traits in the North-Swedish trotter. (In German.) Z. Tierz. Züchtungsbiol. 92:164. Schwark, H. J., and H. Freund. 1976. Effective selection criteria in the performance testing of trotters (In German). II. Internat'l Wissenschaftliches Symp., Leipzig. (Anim. Breed. Abstr. 47:5297.)

Searle, S. R. 1971. Linear Models. John Wiley and Sons., Inc., New York.

Snedecor, G. W., and W. G. Cochran. 1967. Statistical Methods (6th Ed.). The Iowa State University Press, Ames.

Sokal, R. R., and F. J. Rohlf. 1969. Biometry. W. H. Freeman and Company, San Francisco.

Solá, G. A. 1969. Environmental factors affecting the speed of pacing horses. M.S. Thesis. Ohio State Univ., Columbus.

Swiger, L. A., W. R. Harvey, D. O. Everson and K. E. Gregory. 1964. The variance of intraclass correlation involving groups with one observation. Biometrics 20:818.

Vainikainen, V. 1946. Breeding the Finnish horse. (In Finnish with English summary.) Suom. Maatal. tiet. Seur. Julk. 62:1.

Van Vleck, L. D. 1973. Summary of methods for estimating genetic parameters using simple statistical models. Dept. of Anim. Sci., Cornell Univ., Ithaca, NY.

Varo, M. 1965. Some coefficients of heritability in horses. Ann. Agr. Fenn. 4:223.

Watanabe, Y. 1969. Zeitmessung als Selektionsmasstab in der Vollblutzucht. Japanese J. Zootech. Sci. $40: 271$.

Watanabe, Y. 1970. Zuchtwertschätzung beim Vollbliter. Res. Bull. of the Livestock Farm, Faculty of Agriculture, Hokkaido Univ., No. 5.

Watanabe, Y,, T. Shimoiizaka and K. Sato. 1965. An analysis of the racing performances of Thoroughbreds in Japan. Res. Bull. of the Livestock Farm, Faculty of Agriculture, Hokkaido Univ., No. 1. 